\title{
Studies on Cortisol Secretion Rate, Especially on the Validity of the Method and on the Normal Range for Japanese Adults
}

\section{Ichiro KATSUSHIMA}

2nd Dep artment of Internal Medicine, Tohoku University School of Medicine, Sendai, Japan (Director : Professor Tatsuo Torikai, M.D.)

Details of a procedure for estimating cortisol secretion rate (CSR) were presented and the validity of this method was investigated. Using this method, CSR in normal subjects, in subjects under stress and in patients with adrenocortical dysfunctions were estimated.

1) After an intravenous administration of a treacer dose of cortisol-1,2- ${ }^{3} \mathrm{H}, 24-\mathrm{hr}$. urine was collected. Two major urinary metabolites of cortisol, tetrahydrocortisol (THF) and tetrahydrocortisone (THE), were purified paper-chromatographically and their specific activities were determined by liquid scintillation counting and Porter-Silber method: The estimated value of CSR was calculated by dividing total administered radioactivity by the specific activity of THF or THE.

For purifying both THF and THE, ethylene dichloride-formamide system was used as the first paper chromatography. In the next step, Bush $B_{5}$ system was used for purifying THF, and E2B system or Bush $\mathrm{B}_{5}$ system for purifying THE.

2) When E2B system was used as the second paper chromatography for purifying THE, two values of CSR, wihch were independently calculated from the specific activity of THF and from that of THE, did not agree with each other.

In order to find which value reflects more actual cortisol secretion rate, known amounts of cortisol were given to the patients with hypoadrenocorticism, and apparent CSR were estimated. The estimated values agreed with the doses administered when calculation was made from the specific activity of THF, while they showed much smaller values with calculation from that of THE. This fact suggested that cortisol metabolite or metabolites, not Porter-Silber chromogenic, contaminated THE. When Bush $\mathrm{B}_{5}$ system was substituted for E2B system as the second paper chromatography for purifying THE, the values of CSR calculated from the specific activity of THE approached the values from THF.

3) The value of CSR calculated from the specific activity of THF was 14.6 \pm 3.3 (S.D.) $\mathrm{mg} /$ day in 10 resting normal subjects, and was $13.7 \pm 3.2 \mathrm{mg} /$ day in 10 lightly working normal subjects. There was no significant difference between the two groups. A slightly higher value, $17.8 \pm 5.0 \mathrm{mg} / \mathrm{day}$, was obtained from 8 heavy muscle laborers.

4) The value of CSR in 10 resting and 10 lightly working normal subjects, $14.1 \pm$ $3.2 \mathrm{mg} /$ day, agreed with the smallest normal value that was previously presented by 
foreign investigators. This may be due to the smaller body size of Japanese people than that of foreign people.

At the same time, CSR in subjects under stress and in patients with adrenocortical hyper- and hypofunctions were studied. From these data, it was finally justified to adopt $7.8 \sim 20.5 \mathrm{mg} /$ day as the normal range.

$\mathrm{Ir}_{\perp}$ addition, CSR per $\mathrm{kg}$ of body weight and per $\mathrm{m}^{2}$ of body surface area were also evaluated. The adopted normal ranges were $145 \sim 358 \mu \mathrm{g} / \mathrm{kg} / \mathrm{day}$ and $5.3 \sim 12.6$ $\mathrm{mg} / \mathrm{m}^{2} /$ day.

(pp. 1232 1247) 


\title{
Cortisol 分泌量に関する検討
}

\section{とくに測定法並びに正常範囲について}

\author{
東北大学医学部鳥飼内科（持導：鳥飼龍生教授） \\ 勝島 一 郎
}

(昭和 41 年 10 月 13 日受付)

\section{第 1 章 緒言}

Cortisol 代謝産物の尿中排泄量によつて副腎からの cortisol 分泌量を推測する手段として，尿中17-OHCS や尿中 17-KGS か測定されている。乙れらの方法にはそれぞれの利点も認められるが，回収率や特異性が 当然問題となりうる. 又もしてれら測定法に伴う誤差を僅少にとどめ得たとしても, 分泌された cortisol の 何\%がてれらの steroids 亿变換されるかは，体内にわける cortisol 代謝の様相の個体差に左右されるため， 単なる安静時の測定により副腎皮質機能を推測するととは多分の危険を伴うと考学られる.

これに対し isotope dilution method による cortisol 分泌量の測定は, 原理的に回収率, 体内代謝, あ るいは特異性によつて起る問題を一挙に解消せしめうると思われ，もし正確に実施されるなら，副腎皮質機 能の究極的な指標の一つとなりうると考えられる.

しかし従来の cortisol 分泌量に関する報告によれば，後述するように，同じ民族あるいは同じ地域住民に おける測定の結果でも，報告者によりかなりの隔りがみとめられる。それにも拘らず，測定法の精度に関し ての研究か殆んぞみられないのは不思議に思われる。

著者は，測定法の上で系統的誤差を生じうる多くの技術的問題のあるてとを予想して，てれに関する検討 を行なつて来た。 今回はその結果てれまでに得られた最終的な測定法を，測定法の精度に関して行つた検討 とともに報告する，又との方法を用いて本邦健常成人20例における分泌量を測定し，その值をストレス時に おける值及び副腎皮質機能異常症例における值と対比するととにより，正常範囲を設定した，その結果を併 せて報告する。

\section{第 2 章＼cjkstart実験対象および実験方法}

\section{I 実験対象}

安静時の cortisol 分泌量を測定するための正常対照例としては, 鳥飼内科偟入院中の軽症成人患者のうち, 肝・および腎機能に異常なく，内分泌学的にも異常の認められない男子 5 例および女子 5 例を選んだ.

軽学働負荷時の分泌量測定のための正常例としては，某炭鉱従業員中，坑外で軽学㗢に従事していた成人 男子10例を対象とした.

重学衝時の分泌量測定のための正常例は，同じく某炭鉱従業員で，気温 $28 \sim 33^{\circ} \mathrm{C}$, 湿度 $75 \sim 92 \%$ という高 温高湿下の坑内で, 午後 2 時から 10 時迄採炭に従事していた成人男子 8 例である.

諸疾患患者としては計25例を対象とした。その内訳は，Cushing 症候群 3 例，甲状腺機能元進症 6 例， 単純性肥満症 3 例, 進行性麻痺 (発熱療法中) 1 例, 脊椎分離症 (持続骨盤率引中) 1 例, Addison 病 5 例, 諸種の原因による汎下垂体機能低下症 5 例及び潰瘍性大腸炎(AGTH-Z 40単位 1 日 2 回筋注 13 日目) 1 例で ある.

\section{II 実験方法}

重学働中の正常例の場合は，午後 2 時の入坑直前に排尿させ，放射性 cortisol を静注し，以後容量 21 ポ 
リエチレンタンクを携帯せしめて 24 時間蓄尿させた，その他の被験例の場合は，原則として午前 9 時と 11 時 の間に最後の排尿を行なわせ，直ちに放射性 cortisol を静注し，24時間室温で蓄尿させた，

蓄尿容器には予め dihydrostreptomycin sulfate $0.5 \mathrm{~g}$ 及び氷性 penicillin 10 万単位を加光, 蓄尿終了後 直ちに操作に入ら奴場合は, 容量500ccのポリエチレンタンクに入れ, $-20^{\circ} \mathrm{C} の$ deep freezer 又は dry ice で涷結保存した。

cortisol 分泌量は Cope and Black ${ }^{23)}$ にしたがい，24時間尿中の cortisol 代謝産物の比放射能から算出し た(第 3 章)。体表面積は DuBois-Boothby-Sandiford によつた。

III 特 例

ての他に第 3 章VII及び第 4 章 I においては，その項に記載した実験対象および実験方法によつて実験を行 なつた。

\section{第 3 章 Cortisol 分泌量測定法}

概略を Fig. 1 に示した.

\section{I 放射性 cortisol 注射液の調整法}

\section{Series 1 の注射液}

Radiochemical Centre (英国 Amersham) より 入手した cortisol-1,2- ${ }^{3} \mathrm{H} 500 \mu \mathrm{C}$ （比放射能 $6.1 \mu \mathrm{C}$ / $\mu \mathrm{g})$ の benzene-methanol 溶液を, acetone-dry ice で凍結せしめた後開封し, methanol 註 1 をもつて 減圧乾固用の容器に移し， $45^{\circ} \mathrm{C}$ で乾固し，E2B ${ }^{1)}$ 及 び Bush $\mathrm{B}_{5}$ system $^{2}$ で精製した. Bush $\mathrm{B}_{5}$ system の paper chromatogram は scanning により放射 能の分布を調べ， main peak 相当部分を切りとつ た．紙片の下部を V 字型に cut し，上部中央を水 平に差し出した針に突き刺して吊し，ビユーレット より滴下する pure ethanol をもつて溶出し, 50cc に稀釈した。 こうして精製された carrier-free の cortisol-1, 2-'H の ethanol 溶液は, ツベリクリン 用注射器をもつて 1 ccづつ滅菌 ampoule に分注し, 窒素ガスとともに封入した。 このseries の ampoule

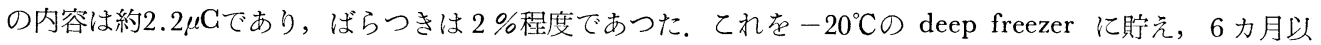
内に使用した。

\section{Series 2 の注射液}

New England Nuclear Corporation (Boston) より入手した cortisol-1,2- ${ }^{3} \mathrm{H} 1 \mathrm{mC}$ (比放射能 $2 \mu \mathrm{C} / \mu \mathrm{g}$ ) を series 1 の方法で乾固し，未精製のまま pure ethanol $100 \mathrm{cc}$ に溶解し， $1 \mathrm{cc}$ づ ampoule つに分注し，

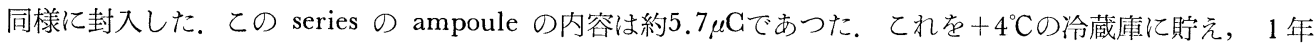
以内に使用した。

\section{II 放射性 cortisol の投与法}

20cc用の注射器に約21ccの生理的食塩水を吸引儿, 放射性 cortisol (通常は 1 ampoule, 分泌量が高值を 示すと予想された場合には 2 ampoule) を吸引し，注射液を何回か ampoule 内に出し入れして，完全に 放射能を収容するよう努めた。. 次で $2 \sim 3 \operatorname{cc} の$ 空気を吸引した後 $5 \sim 6$ 回注射器を倒立させて内容を混和し，

註 1 ：試薬は，特記したむのを除き，すべて関東化学製特級をそのまま使用した。 
空気を排除した。内容の数滴を棄て，ついで正確に20ccを残して余分を glass stoppered tube に取り分け， 残り $20 \mathrm{cc}$ を実験対象例传静注した。

glass stoppered tube から正確に 1 cc (投与量の1/20) を counting vial (Packard 社) に移し, Bray ${ }^{8}$ の処方による scintillator $10 \mathrm{cc}$ を加光て総量を11 ccとし, liquid scintillation counting に供した。

III 24時間尿中 tetrahydrocortisol (THF) 及び tetrahydrocortisone (THE) の分離精製法

尿検体として一般には24時間尿の200ccを用いたが，症例によつては100〜2000ccを用いた。このように用

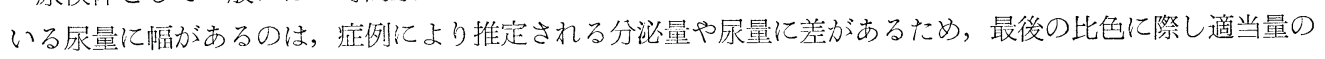
steroid を得んがためである。

てれを等容の ethyl acetate で 1 回 pre-extract した後, 尿量100ccにつき dihydrostreptomycin sulfate $0.1 \mathrm{~g}, 0.3 \mathrm{~mol}$ phosphate buffer ( $\mathrm{pH}$ 6.8) 15cc, chloroform 数cc及び細菌性 $\beta$-glucuronidase (Sigma 社) 5000 単位を加え, $\mathrm{pH} 6.8$ 亿調整し, $38^{\circ} \mathrm{C} て ゙ 18$ 時間 incubate した.

ついで等容の ethyl acetete で 2 回抽出し, 前後の抽出液を別々の分液漏斗に入れたまま, 前者の洗深液 を後者で逆抽出すると同時に後者を洗涤する形で，1/10容量の $1 / 10 \mathrm{~N} \mathrm{NaOH}$ および蒸溜水で 2 回づつ洗涤 した後両者を併せ, $45^{\circ} \mathrm{C}$ で減圧乾固した。

次に内径 $1 \mathrm{~cm}$ の column に 100 mesh の silica gel (Mallinckrodt 社) $2.5 \mathrm{~g}$ t chloroform 湿式に充填 し, crude extract を chloroform に溶解して吸着させた。 ついで $1 \%$ acetone in chloroform 50cc, その 後 $50 \%$ acetone in chloroform 100cc で加压溶出した。 2 度目の溶出液を減圧乾固し, ethylene dichlorideformamide system ${ }^{334)}\left(25^{\circ} \mathrm{C}\right)$ により18〜24時間展開した註 2 .

paper chromatogram $445^{\circ} \mathrm{C}$ の温風により乾燥させた後, 中央 $3 \mathrm{~mm}$ 幅の細長い紙片を切り出し, blue tetrazolium (第一化学) で発色させ，乙の両側 $3 \mathrm{~cm}$ 幅の紙片は $4 \pi$ paper strip scanner (日本無線医理学 研究所）により放射能の分布を調へ，两者を指標として往 3 THF + ATHF (allotetrahydrocortisol) および THE 相当の $2 つ \bigoplus$ band を切りとり, 両分画を別々に溶出し乾固した.

ついで両分画は chloroform $25 \mathrm{cc}$ で溶解して別々の遠沈管に移し, 尚管壁に付着する残渣は各々蒸溜水 5 ccで溶解して遠沈管内の chloroform と併せ, 両相の液体分配により, 次の paper chromatography で tailing の原因となる残余 formamide を水層に移行させて除去した5)10). 水層は更に chloroform $25 \mathrm{cc}$ で 抽出し, 前後の chloroform を併せて減圧乾固した。

こうして得られた formamide-free の THF+ATHF 分画は, Bush $B_{5}$ system維 $4\left(28^{\circ} \mathrm{C}\right)$ そより 5 時間〜

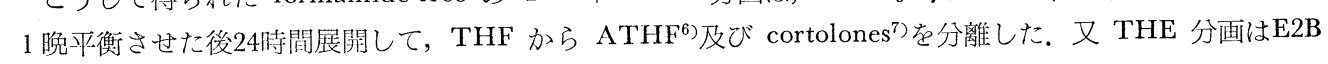
system詳 5 で展開するか, 或は Bush $\mathrm{B}_{5}$ system $\left(28^{\circ} \mathrm{C}\right)$ そより 1 晚平衡させた後 8 時間展開した。

これら final paper chromatogram は 1st paper chromatogram の場合に準じて THF 或は THE 相 当の band 在 mark した上, 乾燥状態で比色当日迄保存した。

IV 投与全放射能, THF 及び THE の比放射能の決定, 並びに cortisol 分泌量の算出

final paper chromatogram の THF 及び THE 相当の band を溶出乾固し, てれを ethanol に溶解

註 2 : chromatography 用 paper としては，すべて Watman No. 1 滤紙を未矮源のまま使用した。 rou一 tine work用に用いたものの寸法は, 大きさ $6.3 \mathrm{~cm} \times 57 \mathrm{~cm}$, paper 上端加ら下降部上端迄 $8 \mathrm{~cm}$, 下降部 上端から starting line 迄 $6 \mathrm{~cm}$ であり，下端をV字型に cut して使用した。

chromatography 用タンクとしては, 内径 $30 \mathrm{~cm}$, 高さ $60 \mathrm{~cm}$ の標本瓶を, 縱横ともに $60 \mathrm{~cm}$, 高さ $105 \mathrm{~cm}$

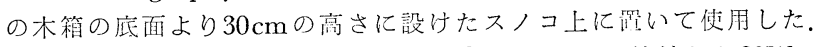

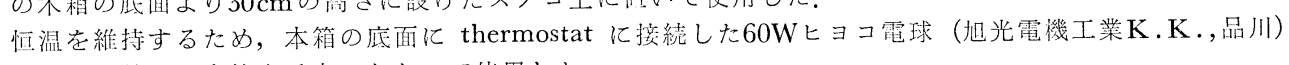
6 渻を取付け，木箱を毛布でおおつて使用した。

註 3 : THF 及び THE の一方又は双方が徽量と予测される場合は, reference steroids を同時展開した。

註 4 ： ヒヨコ電球の点隇とは無関係に, 常時木箱の中で扇風機を回転させ, 木箱内で立体的にも均一の温度 が得られるようにした ${ }^{29}$.

註 $5: 28^{\circ} \mathrm{C}$ で 1 晚脃和させた後, ヒヨコ電球の電源を開放し, 室温で 4 時開展開した。 
したが，その量は，final paper chromatogram 中 央幅 $3 \mathrm{~mm}$ に切りとつた紙片の blue tetrazolium 発色の程度から凡その steroid 量を推定し, それに 従つて 5 20ccとした，しかし通常は $5 \mathrm{cc}$ とた。 その1.5ccづつを counting vial, Porter-Silber反応 に供する sample A 及びBの 2 本の試騟管, 計 3 者に分注した。

\section{Liquid scintillation counting}

counting vial には更に PPOおよび POPOP(い ずれも Packard 社）党溶解した toluene社6 9.5 ccを 加光て総量を $11 \mathrm{cc}$ と，本章IIで作製した投与全放 射能の $1 / 20$ を含吉検体と set にして， 3 channel automatic liquid scintillation counter (Nuclear Chicago 社）により各 channel の cpm を求め, discriminator ratio 法により quenching 花補正し て (Fig. 2), 各検体の含吉 $\mathrm{dpm}$ を算出した註?

計数効率は Bray $の$ scintillator 組成の場合約 11 $\%$, steroid の ethanol 溶液と混和した toluene 溶媒とする場合約 $25 \%$ で，同種の scintillator 組成 では各検体の quenching に殆んど差は認められな かつた，又同量の cortisol-1,2-3 $\mathrm{H}$ を上述 2 種の異 なつた scintillator 組成で計数し, discriminator
Fig. 2. Quenching correction curve for ${ }^{3} \mathrm{H}$ (Nuclear Chicago 3 channel liquid scintillation counter)

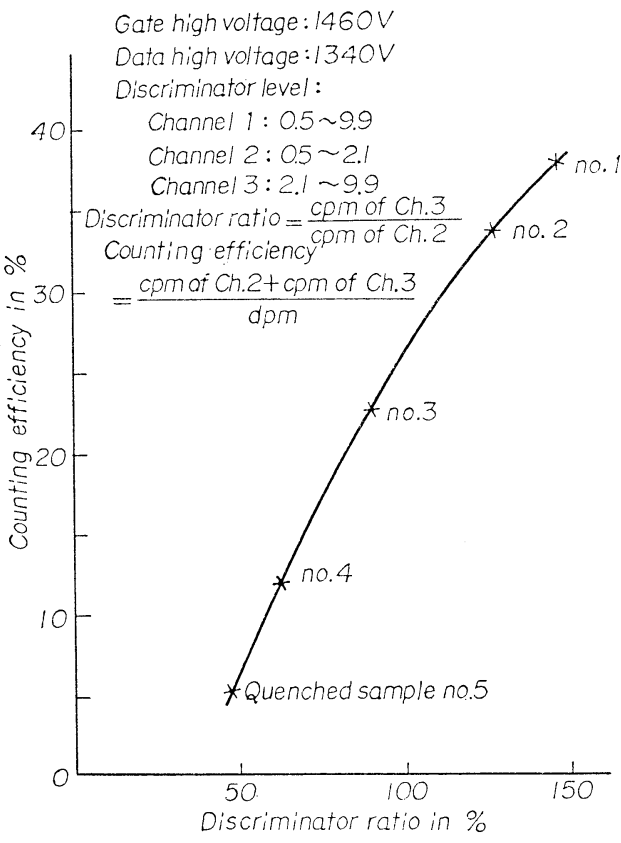

ratio 法により quenching correction を行なつたところ，殆んど同一の dpm が得られた。

\section{Porter-Silber 反応}

sample A 及びBは，Table 1 亿記載した実験条件で，常に対応する標準 steroid 溶液を対照として操 作比色し，それでれ steroid 含量 $(\mathrm{mg})$ を求めた。

\section{分泌量の算出}

THF 及び THE の放射能 $(\mathrm{dpm})$ を，それぞれの重量 $(\mathrm{mg})$ で除して各々の比放射能 $(\mathrm{dpm} / \mathrm{mg})$ を求め,

Fig. 1 に示した式に従つて分泌量を算出した.

\section{THF 及び THE 標準物質の純度に関する検討}

著者がPorter-Silber 反応に際して標準物質として使用した THF 及びTHE は，いずれも Merck Sharp \& Dohme社より贈られたもので，THEは良質のものであるが，THF は約 $3.5 \% の$ more polar compound を含むとされだ．岡本 ${ }^{10)}$ とれば，D.K. Fukushima より贈られた THF とATHF は同一の Porter-Silber chromogenicity を有したといわれる。著者は岡本より贈られたこの ATHF, Zori 社(Israel)のATHF 及 び Upjohn 社より贈られた THE を, 上述の標潐物質とともに Table 1 の方法により発色させたところ, THF 標淮物質は雨 ATHF と, 又 THE 標準物質は Upjohn 社の THE と, 殆んど同一の chromogenicity を有した.

註 6 : PPO (2,5-diphenyloxazole) 及び POPOP[1,4-bis-2-(5-phenyloxazolyl)-benzene] は, counting vial 内での最終濃度が $1000 \mathrm{cc}$ 中それぞれ $4.0 \mathrm{~g}$ 及び $0.1 \mathrm{~g}$ となるように，予め toluene 飞溶解して扔いた。

註 7 ：殊飞高温高湿時には quenching correction curve が shift することが認められたので，使用の少な くも 2 時間前功 room cooler を作動させ, 同洔に liquid scintillation counter の warming-up を行 なつた。 又一連の测定の前後に求いて quenching correction curve を作製し, 测定中に shift のほとん ぞないととを確めた。 
Table 1. Porter-Silber chromogenicity of THF and THE experimental conditions :

Reagents : Sulfuric acid-water solution : conc. $\mathrm{H}_{2} \mathrm{SO}_{4} /$ Water $=56 / 44(\mathrm{~V} / \mathrm{V})$

Phenylhydrazine-sulfuric acid reagent : $92 \mathrm{mg}$ phenylhydrazine sulfate in 100cc sulfuric acid-water solution

Quantities

of reagents : Sample A : steroid in $1.5 \mathrm{cc}$ ethanol $+3 \mathrm{cc}$ phenylhydrazine-sulfuric acid reagent

Sample B : the same quantity of steroid as sample A in $1.5 \mathrm{cc}$ ethanol $+3 \mathrm{cc}$ sulfuric acid-water solution

Blank a : $1.5 \mathrm{cc}$ ethanol $+3 \mathrm{cc}$ phenylhydrazine-sulfuric acid reagent

Blank b: $1.5 \mathrm{cc}$ ethanol $+3 \mathrm{cc}$ sulfuric acid-water solution

Incubation : At $60^{\circ} \mathrm{C}$ for $30 \mathrm{~min}$.

Colorimetry : Optical density of sample A was read in reference to blank a (A-a) and of sample B in reference to blank $\mathrm{b}(\mathrm{B}-\mathrm{b})$ at $410 \mathrm{~m} \mu$ by Beckman $\cdot \mathrm{DB}$ spectrophotometer.

Calculation : Optical density $=(A-a)-(B-b)$

Result :

\begin{tabular}{c|c|c|c}
\hline Steroid & THF* & THE & THF*/THE \\
\hline \hline Mean \pm S.D. & $9.10 \pm 0.45$ & $11.48 \pm 0.62$ & $79.5 \pm 7.6 \%$ \\
\hline
\end{tabular}

Unit : $\quad$ Optical density/mg steroid in sample A

No. of

experiment : 6

* This substance was stated to contain about $3.5 \%$ of more polar compound.

著者の標準物質の Porter-Silber chromogenicity を Table 1 に示した.

VI 投与した放射性 cortisol の radiopurity に関する検討

本章 I により作製した series 2 の注射液を, $+4{ }^{\circ} \mathrm{C} の$ 泠蔵庫に 1 年間保存した後開封し, 減圧乾固用の ガラス容器に移し， acetone-dry ice で冷脚した trap を媒介として真空ポンプで吸引，固形相と ethanol 相に分離した. liquid scintillation counting の結果, ethanol 相の全放射能は固形相のそれの0.2\%にすぎ なかつた。 したがつて tritium が保存中に steroid 核から離脱するととはほとんどないと考えられた。

次に固形層に E2B 及び Bush $\mathrm{B}_{5}$ system で精製した carrier cortisol を加え，一部を取り分け，残りを E2B system で展開した. paper strip scanner で scan した結果 cortisol の main peak の他に, origin 及び solvent front に接してそれぞれ小さな perk を認め，てれら peak に狭まれた部分にも若干の放射能 を認めた。 それぞれの部分を溶出して liquid scintillation counting を行なつたところ, main peak への 放射能の配分は91.0\%であつた.

一方 main peak の cortisol の一部を更に Bush $B_{5}$ system で精製し，全精製過程の前 後における cortisol の比放射能を測定比較す ると，精製後の 比放射能は精製前のそれの $102.6 \%$ という值を得た。したがつて，ての 場合の放射性 cortisol の radiopurity はほ ぼ100\%であり，前述の $91.0 \%$ という数字は E2B system の回収率を表現しているものと 判断した.

本章 I に明らかなように，すべて被験例に 投与した放射性 cortisol は，乙こに分析した ものよりも radiopurity が高いと考光られ

Table 2. Ratios of specific activities (\%) of THF and THE of $2 \mathrm{nd} 24 \mathrm{hr}$ urine to those of 1st $24 \mathrm{hr}$ urine after administration of cortisol-1,2- ${ }^{3} \mathrm{H}$ in an Addisonian patient maintained on various doses of cortisol

\begin{tabular}{c|c|c}
\hline $\begin{array}{c}\text { Dose of cortisol } \\
\mathrm{mg} / \text { day }\end{array}$ & THF & THE* \\
\hline 80 & 2.1 & 2.3 \\
60 & 2.2 & 15.6 \\
40 & 2.9 & 1.9 \\
\hline
\end{tabular}

* Purified by E2B system.

Above experiments were performed to examine if $24 \mathrm{hr}$ period of urine collection suffices. 
る条件で使用した。

\section{24時間採尿の妥当性に関する検討}

分泌量測定に際して，24時間という採尿期間間が妥当か否かを検討するため，Table 2 に示したように Addison 病患者を 3 段階の一定量 cortisol で維持 $(80,60,40 \mathrm{mg} / \mathrm{day}$ ，いずれも 1 日 2 回に分服) し, 放射 性 cortisol 投与当日および翌日の各24時間尿の THF 及び THE の比放射能を測定比較した.

1 日60mgの cortisol で維持した場合，放射性 cortisol 投与翌日尿の THE の比放射能は，当日尿の THE の比放射能の $15.6 \%$ とう無視出来ない值を示したが，1 日 $80 \mathrm{mg}$ および1 日 $40 \mathrm{mg}$ で維持した場合は， ともに $3 \%$ 以下にとどまつた。

Flood $~^{15)}$ によれば，正常 5 例に tracer dose の cortisol-4 ${ }^{-14} \mathrm{C}$ を投与した場合，投与放射能の56〜 66\%， 平均 $62 \%$ が当日尿の glucuronide fraction として, 又 $0.6 \sim 1.7 \%$, 平均 $1.1 \%$ が翌日尿の glucuronide fraction として排泄されたといわれる。

てのととも含めて判断すれば，15.6\%という1例は例外的なものと考光られる。したがつて，24時間採尿 は完壁とはいえないが，そのととにより生ずる測定值の誤差は，一般に数\%以下にとどまるものと考光られ た.

\section{第 4 章 実験結果並びに考按}

\section{I 測定法全体としての信頼性に関する検討}

健常者及び諸疾患患者における cortisol 分泌量を測定した。乙の場合THEの精製に，まずE2B system を用いるとととした。その結果は，THF から算出された分泌量と， $、 T H E$ から算出された分泌量は一般に 一致せず，後者は前者の $87 \pm 20$ (S.D.)\%に分布していた(Table 3).

Table 3. Comparison between values of CSR calcurated from THF and those from THE (The former were assumed to be $100 \%$.) and also comparison of these values in apparent CSR to doses of cortisol administered to patients with hypoadrenocorticism (The doses of cortisol were assumed be 100\%.)

\begin{tabular}{l|r|r|r|r}
\hline \hline Metabolite from which CSR calculated & THF & \multicolumn{2}{|c}{ THE } \\
\hline Final paper chromatography system & $\mathrm{n}=62$ & 100 & $87 \pm 20$ & \\
\hline \hline CSR of normal subjects \& patients & $\mathrm{n}=9$ & $99 \pm 26^{*}$ & $62 \pm 27$ & \\
Apparent CSR in hypoadrenocorticism \\
$\begin{array}{l}\text { (Dose of cortisol=100) } \\
\text { CSR of patients }\end{array}$ & $\mathrm{n}=7$ & 100 & & $95 \pm 2^{* * *}$ \\
\hline
\end{tabular}

When Bush $B_{5}$ system was used as the second paper chromatography for purifying both THF and THE, the values of CSR calculated from THE aproached those from THF, yet small discrepancy $(5 \pm 2 \%)$ remained.

Greater S.D. in apparent CSR* than in ordinary CSR** was ascribed to non-steady state induced by intermittent cortisol administration.

両者のいずれがより真の分泌量を反映するかを检討するため，一定量の cortisol（1 日20～160mg，1〜 4 回に分服）により維持されている hypoadrenocorticismの症例について見かけの分泌量を測定した. THF から算出された分泌量は平均值としては cortisol 投与量を反映したが，THE から算出された分泌量は， 明らかに投与量より低い值を示した(Table 3)。つまり THE の比放射能が大きすぎるととが判明した.

ての原因としては cortisol の metabolite でありながら Porter-Silber chromogenic でない物質が THE を contaminate しているととが考光られた，そてで THE の精製に，此度は E2B system の代りに Bush 
Table 4. Specific activities (dpm/ug) of THF and THE of $24 \mathrm{hr}$ urine of 3 patients admininistered with corticosterone- $1,2-{ }^{3} \mathrm{H}$

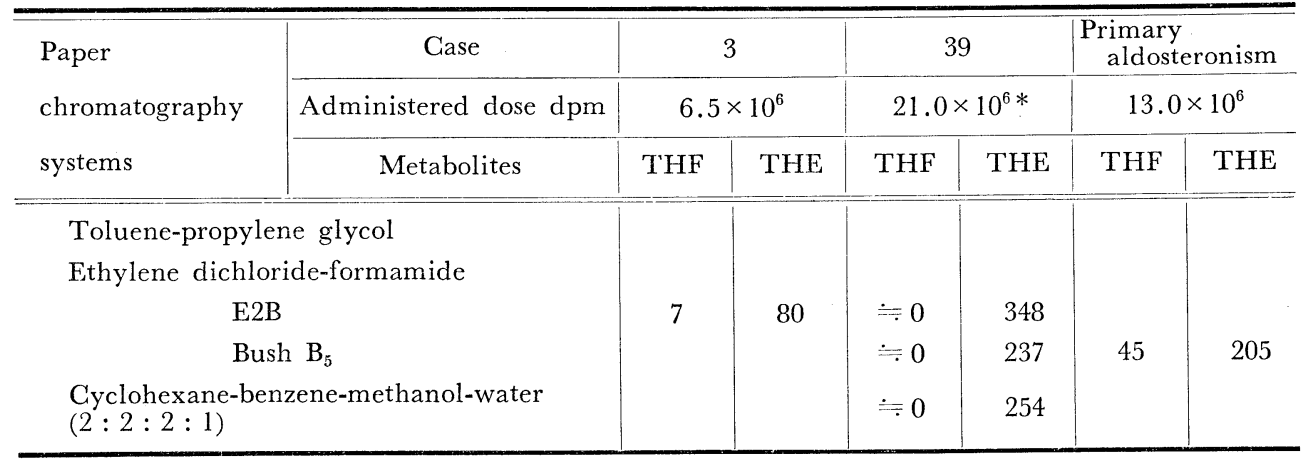

* Purified by E2B and Bush $\mathrm{B}_{5}$ system.

As the cause of the fact that GSR calculated from THF is a little larger $(5 \pm 2 \%)$ than those from $\mathrm{THE}$, it was suspected that corticosterone was converted to $\mathrm{THF}$, giving rise to dilution of radioactivity of THF.

But the above data suggest that corticosterone is converted to THE, but almost not to THF.

$\mathrm{B}_{5}$ system を用いてみたとてろ，雨 metabolite か らの算出值は遙かによい一致を示すようになつた (Table 3). しかしなお 5士2(S.D.)\%の差を残した. この差の原因となりうる事項としては，THF 及 び THE 雨標準物質の純度の相違, paper chromatography 上の問題，及び放射性 cortisol と内 因性 cortisol の代謝の相違の3つが考えられる. S.D. $\pm 2 \%$ という值は，比放射能決定時の統計的鿁 差で充分に説明しうると思われる小さな值であり， したがつて差の $5 \%$ という值は再現性の高い比較的 確実な值と考えられる。乙のような特長をもつもの として, 上述 3 つの可能性のうち, THF 及びTHE 両標準物質の純度の相違を第 1 にあげるととが出来 る. THF 標準物質が約 $3.5 \%$ の不純物を含むとと が既に表明されており，乙の不純物が Porter-Silber chromogenic でないと仮定して補正を行なえばこ の差が更に縮小されるととからも，同じことが暗示 される。しかし他の 2 つの可能性が完全に否定され たわけではない.

THF から算出された分泌量が幾分なりと高值を 示したととの原因として， C-21 corticoids のうち では cortisol の次に分泌量の多い corticosterone が，THFと分離しにくい Portex-Silber chromogen
Table 5. Specific activeties of THF, ATHF and THE of 24hr urine of 2 Addisonian patients orally administered with cortisol of definite specific activity $(136 \mathrm{dpm} / \mu \mathrm{g} \equiv 100 \%)$

\begin{tabular}{c|c|c|c}
\hline \multirow{2}{*}{ Gase } & \multicolumn{3}{|c}{ Specific activity $(\mathrm{dpm} / \mu \mathrm{g})$} \\
\cline { 2 - 4 } & THF & ATHF & THE* \\
\hline \hline 43 & $\begin{array}{c}150 \\
(110 \%)\end{array}$ & $\begin{array}{c}142 \\
(104 \%)\end{array}$ & $\begin{array}{c}123 \\
(90 \%)\end{array}$ \\
\hline 47 & $\begin{array}{c}169 \\
(124 \%)\end{array}$ & & $\begin{array}{c}150 \\
(110 \%)\end{array}$ \\
\hline
\end{tabular}

* Purified by Bush $\mathrm{B}_{5}$ system.

It was also suspected that cortisol-1,2- ${ }^{3} \mathrm{H}$ was more easily dehydrogenated at carbon-11 than ordinary cortisol, resulting in higher spesific activities of THE than those of THF.

But the above data suggest there may be no such probability.

Therefore, it was considered that standard THF the author used in colorimetry may contain about $5 \%$ of non Porter-Silbler chromogenic impurity.

In any way, the discrepancy is so small that it may not invalidate the present method.

The above data also suggest there is no probability that tritium is released from steroid nucleus either during in vivo metabolism or during in vitro experimental procedure. に代謝され排浛されて，THF の放射能を稀釈するととが想定される.

この可能性を検討するため，計 3 例に corticosterone-1，2- ${ }^{3} \mathrm{H}$ を静注し，24時間尿中の THF 及び THE の比放射能を測定した (Table 4)。乙の結果は想定とは逆に，THF 分画にはほとんど放射能が認められず， 
むしろ THE 分画に全例でかなりの放射能が認められ，内1例では精製を重ねるととによりほぼ connstant specific activity に到達するのが認められた。とのととから corticosterone がむしろ THE に変換される ことが示唆された。

一方, cortisol-1，2-3 $\mathrm{H}$ が内因性 cortisol よりも 11-dehydrogenation を受けやすく，その結果 THE の 比放射能が大きくなるのではないかという想定も成り立つ.

このととを検討するため，cortisol-1, 2- ${ }^{3} \mathrm{H}$ と通常の cortisol （1例につき約 $50 \mathrm{mg}$ ）を混和し， 2 例の Addison 病患者に 1 回に内服させて，24時間尿中の THF 及び THE の比放射能を測定した(Table 5). しかしその結果は，想定とは逆に，2例とも THF の比放射能がわずかに大きい值を示した。（尚この場合 に, 各 metabolite の比放射能か投与 cortisol のそれとほぼ一致したてとから, 体内の代謝過程或は排泄後 の実験操作中に於ても, tritum が steroid 核汃ら離脱するてとはほとんどないと推定される。）

したがつて以上 $2 つ の$ 想定は， 5 \%差の明快な説明とはなり得ないように思われる. 結局 THF 標潐物質 には 5 \%程度の non Porter-Silber chromogenic な不純物が含まれていることか疑われる。

見かけの分汼量の実験において，THF から算出された分必量は，投与 cortisol 量の $99 \pm 26 \%$ あ゙すた (Table 3). 乙の成績からは，乙の場合の測定法全体としての系統的誤差が，あつたとしてもあまり大きく はないと推定出来るだけで，測定值の統計的詋か $26 \%$ とあまりに大きいため，目的とした系統的誤差を正確 に見積るととは出来なかつた。

しかし両 metabolite の比放射能から算出された分泌量が $5 \pm 2 \%$ とう僅少の差で一致しているととか ら，両 metabolite にはもはや THE を E2B system で精製した場合に見られたような contamination は あり得ないと判断される. 又, その他の系統的誤差の原因となりうる事項については，てれ迄に述べた如く すへて一応の検討を終つており，いずれも大きな系統的誤差の原因とはなり得ないと推定或は判断されるの で, 測定法全体としてみた場合にも，大きな系統的誤差はないと考学られる.

次に測定法全体としての統計的誤差について考察してみたい.

THE の精製に Bush $B_{5}$ system を用いるとととして cortisol 分泌量を測定した場合, THF から算出し た值と THE から算出した值との差の統計的誤差が S.D. $\pm 2 \%$ とさかつたととは，与えられた尿検体に関 しては, THF 及び THEの比放射能の測定が高度の再現性をもつて行なわれているととを示すものと解さ れる。しかし測定法全体としてみた場合 には，乙の他にも二, 三の統計的䛊差を 生じうる要因が存在する, 即ち, 投与全 放射能の評洒に関連する事項として，20 cc注射器の目盛の正確さや quenching correction curve の微細な shift な゙゙が 誤差の原因となり得る. 又, 尿検体中の THF 及び THE の比放射能を予め規制 する事項として, 蓄尿の正確さが問題と なり, 又もし正確に蓄尿されたとして も，24時間中に標識された THFやTHE を完全に排泄しきれない度合が，症例に よりいくぶん相違するであろうととも統 計的䛊差の原因となりうる。しかし，い ずれにせよてれらの事項による影響がそ う大きいとは考朰れれい。

これに反し, 見かけの分泌量の測定の 場合に, 統計的誤差が $26 \%$ と非常に大き

Table 6. CSR* of 10 resting normal adults

\begin{tabular}{|c|c|c|c|c|c|}
\hline \multirow{2}{*}{ Case } & \multirow{2}{*}{ Sex } & \multirow{2}{*}{ Age } & \multicolumn{3}{|c|}{ CSR } \\
\hline & & & $\mathrm{mg} /$ day & $\mu \mathrm{g} / \mathrm{kg} /$ day & $\mathrm{mg} / \mathrm{m}^{2} /$ day \\
\hline 1 & $\mathrm{M}$ & 27 & 18.6 & 330 & 11.4 \\
\hline 2 & $\mathrm{~F}$ & 22 & 17.6 & 348 & 12.0 \\
\hline 3 & $\mathrm{M}$ & 33 & 17.2 & 269 & 9.6 \\
\hline 4 & $\mathrm{~F}$ & 38 & 17.2 & 337 & 11.7 \\
\hline 5 & $\mathrm{M}$ & 32 & 15.6 & 293 & 9.5 \\
\hline 6 & $\mathrm{~F}$ & 20 & 14.1 & 266 & 9.5 \\
\hline 7 & $\mathrm{M}$ & 62 & 12.5 & 219 & 7.7 \\
\hline 8 & $\mathrm{~F}$ & 23 & 12.1 & 212 & 7.7 \\
\hline 9 & $\mathbf{M}$ & 29 & 10.4 & 211 & 6.9 \\
\hline 10 & $\mathrm{~F}$ & 20 & 10.3 & 228 & 7.3 \\
\hline \multirow{2}{*}{\multicolumn{3}{|c|}{$\begin{array}{l}\text { Mean } \\
\text { S. D. }\end{array}$}} & 14.56 & 271.3 & 9.33 \\
\hline & & & 3.28 & 53.7 & 1.90 \\
\hline
\end{tabular}

* Calculated from specific activity of THF.

第 42 巻 第 11 号 
かつたととの原因としては，1回 20mg 以上というかなり大量の cortisolが一時 に吸収されたため，定常状態が破壊され て, cortisol の代謝が linear 亿行なわ れなかつたからであらうと考光られる。 ほぼ定常状態下に実施される一般の分泌 量測定に際しこのように大きい統計的誤 差が起りえないととは，正常対照20例の cortisol 分泌量が $14.12 \pm 3.17$ (S.D.)mg/ day (Table 9)であり，乙の場合の S.D. の平均値に対する割合は $22.4 \%$ で，26\% よりもむしろ小であつたてとからも明ら かである。もし測定法に伴う統計的誤差 が S.D.22.4\%以上であると仮定すれば， 正常対照20例の cortisol の真の分泌量 はほとんぞ同一 $(14.12 \mathrm{mg} /$ day) でなけ ればならないととになるが，乙れはこの 群で cortisol 分泌量が後述するように 体重及び体表面積と一応正の相関を示し たことなどと矛盾する。

\section{II 健常成人における cortisol 分泌量}

以下, cortisol 分泌量の算出は THF の比放射能によつた。

本邦健常成人28例における cortisol 分 泌量を，単位体重あるいは単位体表面積 あたりの值とともに，Table 6, 7,8 並 びに Fig. 3 に示した.

その中で，重学働時の分泌量 (Table 8)は, 平均值としては軽労働時 (Table 7)に比しいくぶん上昇していたが，測定 值の大半は俥学働時のそれの分布範囲内 にあつた (Fig. 3)。一方軽労働時 (Table 7) と安静時の正常対照例 (Table 6) とで は分泌量に有意の差がなかつたので，と れらを併せた20例を正常対照例とした。

正常対照20例における cortisol 分泌量の度数分布を Fig. 4 亿示したが，ほぼ正規分布をとるものと解さ れる．乙の群において，分必量は体重及び体表面積と，ともにそれぞれ $\mathrm{r}=+0.326$ の相関を示した。 との 群の分泌量の絶対値，並びに単位体重あたり及び単位体表面積あたりの分泌量の分布篹囲を，平均值， S.D. および平均值 \pm 2 S.D. の簙囲とともに Table 9 亿示した. Fig. 5 にはこの中の分泌量の 絶対值の分布範 囲と平均值を欧米諸彦の報告 $\left.{ }^{11)}{ }^{23}\right)$ と対比して示した.

てれによると，同じ米国内でも，平均值にはだいたい $14 \mathrm{mg} / \mathrm{day}$ から $24 \mathrm{mg} / \mathrm{day}$ 迄のばらつきが認め られる ${ }^{11) \sim 18}$ が，著者の平均值はそれらの中で最も小さい值と一致した，乙の成績は，cortisol 分泌量が体重 及び体表面積と正の相関を示すととから考元て，当然予測されるととろである.
Table 7. CSR* of 10 light muscle workers

\begin{tabular}{|c|c|c|c|c|c|}
\hline \multirow{2}{*}{ Case } & \multirow{2}{*}{ Sex } & \multirow{2}{*}{ Age } & \multicolumn{3}{|c|}{ GSR } \\
\hline & & & $\mathrm{mg} /$ day & $\mu \mathrm{g} / \mathrm{kg} / \mathrm{day}$ & $\mathrm{mg} / \mathrm{m} /$ day \\
\hline 11 & M & 46 & 18.2 & 246 & 9.8 \\
\hline 12 & M & 46 & 16.5 & 316 & 10.8 \\
\hline 13 & M & 31 & 16.2 & 242 & 9.2 \\
\hline 14 & M & 48 & 15.7 & 245 & 9.2 \\
\hline 15 & M & 45 & 14.9 & 271 & 10.1 \\
\hline 16 & M & 45 & 13.6 & 219 & 8.6 \\
\hline 17 & M & 46 & 12.4 & 230 & 8.3 \\
\hline 18 & M & 41 & 10.8 & 223 & 7.6 \\
\hline 19 & M & 36 & 9.6 & 165 & 5.7 \\
\hline 20 & M & 42 & 8.8 & 154 & 5.7 \\
\hline \multicolumn{3}{|c|}{ Mean } & 13.67 & 231.1 & 8.50 \\
\hline \multicolumn{3}{|c|}{ S. D. } & 3.17 & 47.0 & 1.73 \\
\hline
\end{tabular}

* Calculated from specific activity of THF.

Table 8. GSR* of 8 heavy muscle laborers of a coal mine under high temperature $\left(28 \sim 33^{\circ} \mathrm{C}\right)$ and humidity $(75 \sim 92 \%)$

\begin{tabular}{c|c|c|c|c|c}
\hline \multirow{2}{*}{ Case } & \multirow{2}{*}{ Sex } & \multirow{2}{*}{ Age } & \multicolumn{3}{|c}{ CSR } \\
\cline { 4 - 6 } & & & $\mathrm{mg} / \mathrm{day}$ & $\mu \mathrm{g} / \mathrm{kg} / \mathrm{day}$ & $\mathrm{mg} / \mathrm{m}^{2} / \mathrm{day}$ \\
\hline \hline 21 & $\mathrm{M}$ & 33 & 26.8 & 463 & 17.2 \\
22 & $\mathrm{M}$ & 31 & 21.0 & 339 & 13.1 \\
23 & $\mathrm{M}$ & 38 & 19.1 & 354 & 12.7 \\
24 & $\mathrm{M}$ & 41 & 17.8 & 255 & 10.1 \\
25 & $\mathrm{M}$ & 51 & 17.7 & 322 & 11.7 \\
26 & $\mathrm{M}$ & 46 & 16.5 & 289 & 10.7 \\
27 & $\mathrm{M}$ & 39 & 12.4 & 191 & 7.2 \\
28 & $\mathrm{M}$ & 44 & 10.8 & 171 & 6.2 \\
\hline \multicolumn{2}{c}{ Mean } & 17.76 & 298.0 & 11.11 \\
& & 4.97 & 94.2 & 3.47 \\
\hline
\end{tabular}

* Calculated from specific activity of THF. 
Fig. 3. CSR of normal adults

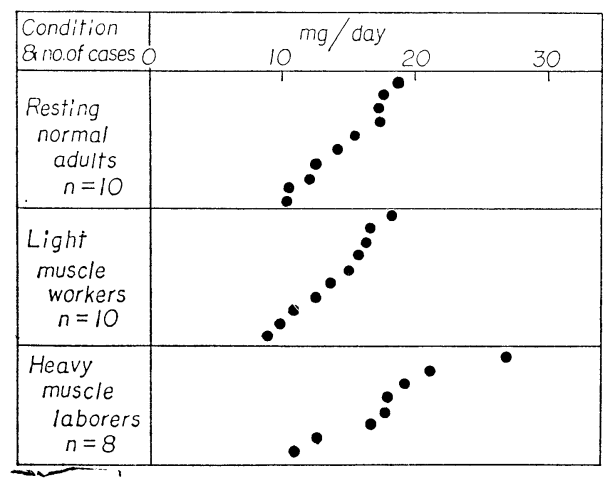

Fig. 4. Frequency distribution of CSR of 20 normal controls

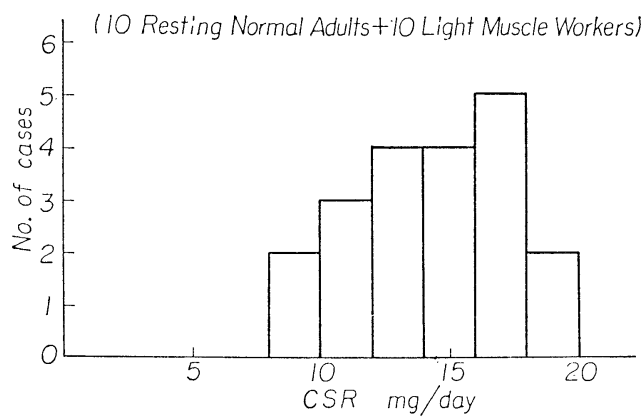

Table 9. CSR* of 20 Normal controls (10 resting normal adults +10 light muscle workers)

\begin{tabular}{l|c|c|c}
\hline \hline & $\begin{array}{c}\text { Absolute value } \\
\mathrm{mg} / \mathrm{day}\end{array}$ & $\begin{array}{c}\text { Per } \mathrm{kg} \text { of body } \\
\text { weight } \\
\mu \mathrm{g} / \mathrm{kg} / \mathrm{day}\end{array}$ & $\begin{array}{c}\text { Per } \mathrm{m}^{2} \text { of body } \\
\text { surface area } \\
\mathrm{mg} / \mathrm{m}^{2} / \mathrm{day}\end{array}$ \\
\hline \hline Range & $8.8 \sim 18.6$ & $154 \sim 348$ & $5.7 \sim 12.0$ \\
Mean & 14.12 & 251.2 & 8.92 \\
S. D. & 3.17 & 53.2 & 1.82 \\
Mean \pm 2 S.D. & $7.8 \sim 20.5$ & $145 \sim 358$ & $5.3 \sim 12.6$ \\
\hline
\end{tabular}

* Calculated from specific activity of THF.

Fig. 5. Means and ranges of distribution of CSR in normal subjects reported by previous authors

\begin{tabular}{|c|c|c|c|}
\hline Country & Source & $\begin{array}{l}\text { Sex } 8 \text { no. } \\
\text { of cases } O\end{array}$ & $10^{. C S R}{ }_{20} \mathrm{mg} /$ day 30 \\
\hline \multirow{8}{*}{ U.S.A. } & Romanoff et al (II) & \begin{tabular}{|r|} 
young 8 \\
elderly 8 \\
\end{tabular} & I \\
\hline & Migeon et al (12) & $\begin{array}{|ll|}M & 15 \\
F & 15 \\
\end{array}$ & $\stackrel{1}{\longrightarrow}$ \\
\hline & Biglieri et al (13) & 19 & $\longmapsto$ \\
\hline & Ney et al (14) & 8 & $\longmapsto-1$ \\
\hline & Flood et al (15) & $\begin{array}{ll}M & 1 \\
F & 5 \\
\end{array}$ & $\longmapsto$ \\
\hline & Layne etal (16) & F 9 & 0 \\
\hline & Steingartetal(17) & .26 & o \\
\hline & Peterson (18) & 14 & $\longmapsto$ \\
\hline Belgium & Nermeulen\&SStraeten(19) & 13 & $\longmapsto$ \\
\hline Perú & Moncloa\& Pretell (2O) & 7 & 0 \\
\hline Canada & Mlynaryket al (21) & 12 & $\longmapsto$ \\
\hline Germany & Karl \& Raith (22) & 18 & $\longmapsto$ \\
\hline England & Cope \& Black (23) & 12 & $\longmapsto-1$ \\
\hline Japan & The author & $\begin{array}{lr}M & 15 \\
F & 5 \\
\end{array}$ & $\longmapsto$ \\
\hline
\end{tabular}


Table 10. Reported means of CSR per $\mathrm{kg}$ of body weight and per $\mathrm{m}^{2}$ of body surface area of normal subjects

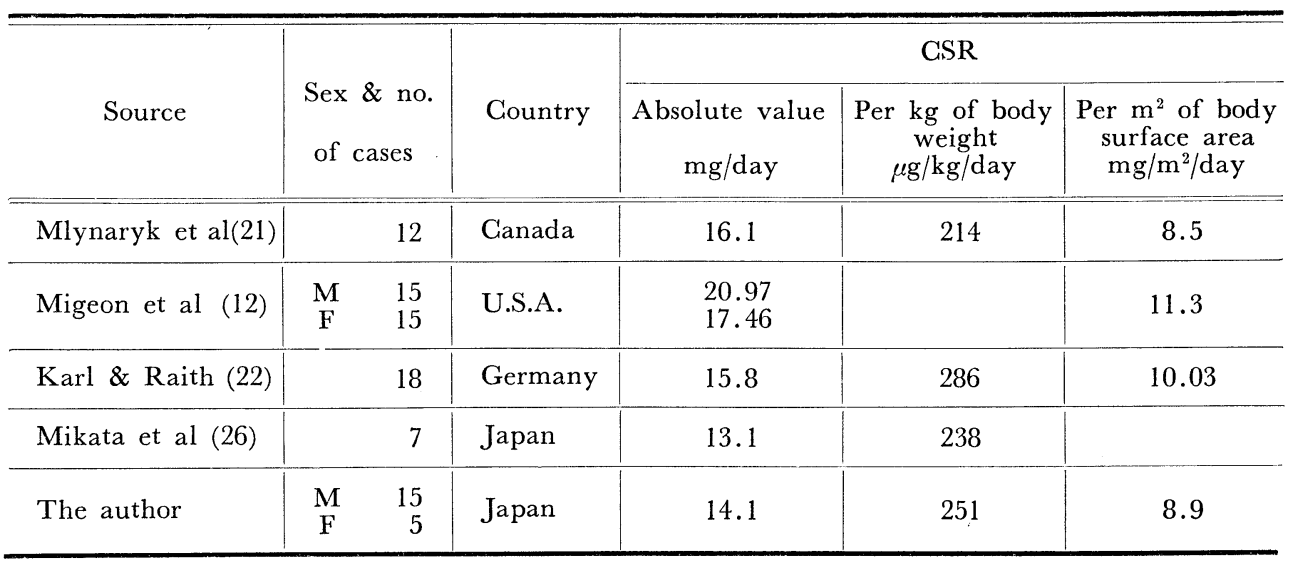

Mlynaryk ら ${ }^{21)}$ 及び Karl and Raith ${ }^{22)}$ は, Table 10 に示すごとく，健常者における単位体重及び単位体 表面積あたりの cortisol 分泌量を報告しているが, 著者の平均値は彼等の平均值の中間に入つた. 又本

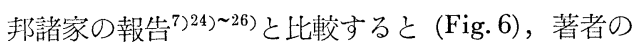
平均值は岡本 ${ }^{7)}$, 井林・村川 $\left.\right|^{24)}$, 及び三方ら ${ }^{26)}$ のそ れと $1 \mathrm{mg} /$ day 以内の差で一致した。

\section{III 本邦成人における cortisol 分泌量の正常範囲}

一般に正常範团は，正常者の測定值の大多数を含 み，異常者をなるだけ多く除外するように選定すべ きものと思われる。

Fig. 6 及び Table 9 そ明らかなように，著者の正常対照20例における cortisol 分泌量の測定值は 8.8mg/ day から $18.6 \mathrm{mg} / \mathrm{day}$ の間に分布しているので，てれをとのまま正常筑囲とすると，平均值では著者と一 致をみた岡本 $\left.{ }^{7}\right)$ 正常 4 例中の最高值 $20.0 \mathrm{mg} / \mathrm{day}$ ，及び同じく井林・村川 (4) $^{24}$ 正常 4 例中の最高值 19.4 $\mathrm{mg} / \mathrm{day}$ を異常と判定するととになる。しかしとの 2 例は辛うじて著者の平均值 \pm 2 S.D. の範冉 (Table 9)に含まれた。 そてで著者はての範盲，つまり $7.8 \mathrm{mg} / \mathrm{day}$ から $20.5 \mathrm{mg} / \mathrm{day}$ までを一応正常範囲と仮定し， てれか研究や臨床診断上の応用に耐えうるか否かを, 正常対照例, 重労働時, あるいは Table 11 に示すよ うなストレス下の症例並びに原発性あるいは続発性に副腎皮質機能の異常を来たしている症例について測定 して得た値と対比して検討した（Fig. 7)。単位体重あたり及び単位体表面積あたりの分必量についても，分 泌量の絶対值の場合と同様にして検討した(Fig. 8 および 9$)$.

まず正常対照20例の cortisol 分泌量は，いずれの場合にも全例，仮定された正常範囲に含まれた(Fig. 7). 正常上界の罗当性に関する議諭として (Fig. 7), まず副腎過形成による Cushing 症候群 3 例は, 軽症のもの も含めて，いずれも明らかな高值を示した。，甲状腺機能元進症では cortisol 分泌の克進することが知られ ているが(727)28)，6例中 1 例が正常上界にあつただけで，他は高値を示した．単純性肥満症でも cortisol 分

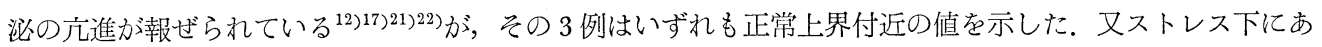
つた例として，チフスワクチン静注により $41.9^{\circ} \mathrm{C}$ 亿達する発熱を呈した進行性麻瘦の症例及び脊椎分離症で 持続骨盤率引中の患者につき測定したが，共に僅かの高值を示すにとどまつた.

以上の検討からは， $20.5 \mathrm{mg} / \mathrm{day}$ という正常上界は，高すぎるととはあつても低すぎるてとはないと考え 
Table 11. CSR* of subjects under stress and of patients having primary or secondary adrenocortical hyper- and hypofunction

\begin{tabular}{|c|c|c|c|c|c|c|c|}
\hline & \multirow{2}{*}{ Disease or condition } & \multirow{2}{*}{ Case } & \multirow{2}{*}{ Sex } & \multirow{2}{*}{ Age } & \multicolumn{3}{|c|}{ CSR } \\
\hline & & & & & $\mathrm{mg} / \mathrm{day}$ & $\mu \mathrm{g} / \mathrm{kg} / \mathrm{day}$ & $\mathrm{mg} / \mathrm{m}^{2} /$ day \\
\hline \multicolumn{2}{|c|}{ Cushing's syndrome } & $\begin{array}{l}29 \\
30 \\
1 " \\
31\end{array}$ & $\begin{array}{l}\mathrm{M} \\
\mathrm{F} \\
11 \\
\mathrm{~F}\end{array}$ & $\begin{array}{l}47 \\
25 \\
26 \\
23\end{array}$ & $\begin{array}{l}54.6 \\
49.1 \\
45.4 \\
31.0\end{array}$ & $\begin{array}{l}834 \\
792 \\
727 \\
525\end{array}$ & $\begin{array}{l}30.7 \\
30.9 \\
28.5 \\
18.2\end{array}$ \\
\hline \multicolumn{2}{|c|}{ Hyperthyroidism } & $\begin{array}{l}32 \\
33 \\
34 \\
35 \\
36 \\
37\end{array}$ & $\begin{array}{l}F \\
F \\
F \\
F \\
F \\
F\end{array}$ & $\begin{array}{l}32 \\
38 \\
26 \\
45 \\
34 \\
35\end{array}$ & $\begin{array}{l}36.9 \\
35.5 \\
34.1 \\
30.6 \\
22.2 \\
20.2\end{array}$ & $\begin{array}{l}749 \\
722 \\
726 \\
764 \\
462 \\
400\end{array}$ & $\begin{array}{l}25.3 \\
24.5 \\
24.4 \\
23.5 \\
15.8 \\
14.2\end{array}$ \\
\hline \multicolumn{2}{|c|}{ Simple obesity } & $\begin{array}{l}38 \\
39 \\
40\end{array}$ & $\begin{array}{l}\mathrm{F} \\
\mathrm{M} \\
\mathrm{M}\end{array}$ & $\begin{array}{l}21 \\
17 \\
55\end{array}$ & $\begin{array}{l}21.5 \\
21.2 \\
20.2\end{array}$ & $\begin{array}{l}287 \\
184 \\
255\end{array}$ & $\begin{array}{r}12.4 \\
9.5 \\
11.2\end{array}$ \\
\hline \multicolumn{2}{|c|}{$\begin{array}{l}\text { During fever therapy } \\
\text { (Progressive paralysis) }\end{array}$} & 41 & $\mathrm{M}$ & 47 & 21.9 & 353 & 13.4 \\
\hline \multicolumn{2}{|c|}{$\begin{array}{l}\text { During continuous pelvic extension } \\
\text { (Spondylolysis) }\end{array}$} & 42 & $\mathrm{M}$ & 20 & 21.5 & 391 & 13.7 \\
\hline \multicolumn{2}{|c|}{ Addison's disease } & $\begin{array}{l}43 \\
44 \\
45 \\
46 \\
47\end{array}$ & $\begin{array}{l}F \\
F \\
F \\
F \\
F\end{array}$ & $\begin{array}{l}22 \\
49 \\
49 \\
42 \\
42\end{array}$ & $\begin{array}{l}7.9 \\
3.8 \\
3.7 \\
3.4 \\
1.6\end{array}$ & $\begin{array}{r}162 \\
75 \\
80 \\
84 \\
42\end{array}$ & $\begin{array}{l}5.7 \\
2.6 \\
2.5 \\
2.7 \\
1.2\end{array}$ \\
\hline \multicolumn{2}{|c|}{$\begin{array}{l}\text { Addison's disease } \\
\text { 3rd day of ACTH-Z 40U. } \\
\text { intramuscular administration }\end{array}$} & $\begin{array}{l}43 \\
44 \\
46 \\
47\end{array}$ & $\begin{array}{l}F \\
F \\
F \\
F\end{array}$ & $\begin{array}{l}22 \\
49 \\
46 \\
42\end{array}$ & $\begin{array}{l}9.4 \\
3.7 \\
4.1 \\
2.7\end{array}$ & $\begin{array}{r}187 \\
74 \\
104 \\
71\end{array}$ & $\begin{array}{l}6.6 \\
2.6 \\
3.3 \\
2.1\end{array}$ \\
\hline \multirow{4}{*}{ 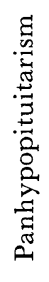 } & Simmonds' disease & $\begin{array}{l}48 \\
\prime \prime\end{array}$ & $\begin{array}{l}\mathrm{F} \\
\prime \prime\end{array}$ & $\begin{array}{c}20 \\
\prime \prime\end{array}$ & $\begin{array}{l}7.4 \\
7.3\end{array}$ & $\begin{array}{l}152 \\
149\end{array}$ & $\begin{array}{l}5.0 \\
4.9\end{array}$ \\
\hline & Ectopic pinealoma & 49 & M & 15 & 2.8 & 71 & 2.2 \\
\hline & Graniopharyngioma & 50 & $\mathrm{~F}$ & 16 & 2.6 & 86 & 2.5 \\
\hline & Sheehan's syndrome & $\begin{array}{l}51 \\
52\end{array}$ & $\begin{array}{l}\mathrm{F} \\
\mathrm{F}\end{array}$ & $\begin{array}{l}37 \\
56\end{array}$ & $\begin{array}{l}1.3 \\
0.7\end{array}$ & $\begin{array}{l}28 \\
12\end{array}$ & $\begin{array}{l}0.9 \\
0.4\end{array}$ \\
\hline \multicolumn{2}{|c|}{$\begin{array}{l}\text { 13th day of ACTH-Z 40U. } \times 2 \\
\text { intramuscular administration } \\
\text { (Colitis ulcerosa) }\end{array}$} & 55 & $\mathrm{M}$ & 40 & 250.0 & 4740 & 166.0 \\
\hline
\end{tabular}

* Calculated from specific activity of THF

られる。実際的には岡本 ${ }^{7} の$ 正常 4 例中の最高値 $20.0 \mathrm{mg} / \mathrm{day}$ をもつて正常上界とするととに矛盾はないよ うに思われた。

重労働時の分泌量は，平均值でみると幾分の増加を示したが，大半は正常範国内にあつた。このととは， 職業として継続するてとが可能な程度の労働によるストレスの大半は, cortisol 分泌量測定によつては識別 しえないとと走すものと解される。

次に，著者の仮に設定した正常範囲 $7.8 〜 20.5 \mathrm{mg} / \mathrm{day}$ に扔ける正常下界の妥当性に関して考察してみた い.

まず著者の Addison 病 5 例中 4 例は明らかな低値を示した。しかし肥満し，色素沈着以外にはつきりし 第 42 巻 第 11 号 
Fig. 7. CSR of normal subjects, of those under stress and of patients with primary or secondary adrenocortical hyper- and hypofunction

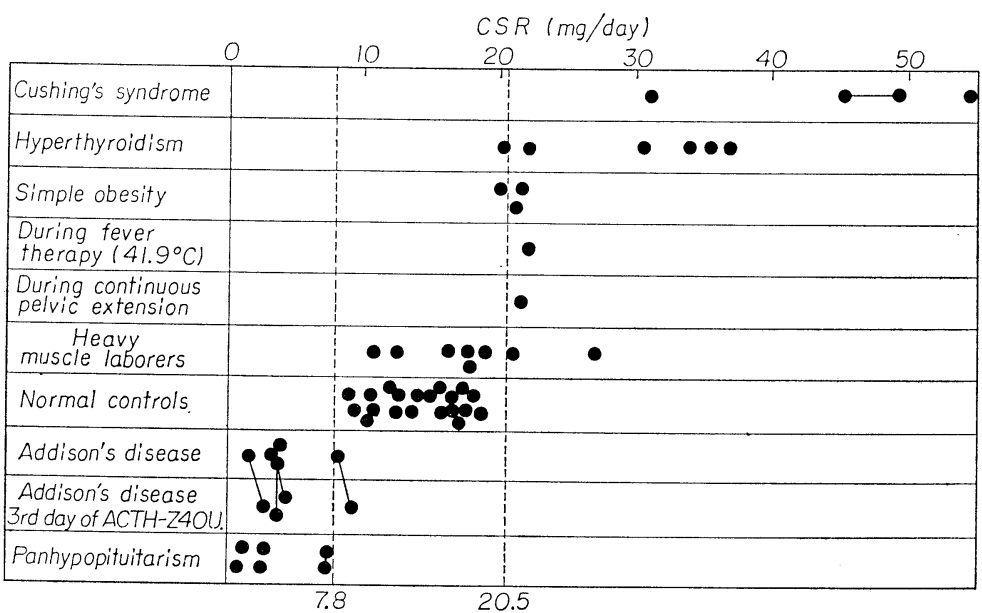

Dotted lines indicate the mean \pm 2 S.D. of CSR in 20 normal controls, which may be justified as the normal range if one compares CSR in normal controls and those in subjects under stress or with various adrenocortical dysfunctions.

Two pateints (one with Addison's disease and the other with Simmonds' disease) who had CSR of lower limit of normal did not require glucocorticoid substitution.

It should be noted that most of heavy muscle laborers had normal values of CSR.

Fig. 8. CSR of normal subjects, of those under stress and of patients with primary or secondary adrenocortical hyper- and hypofunction

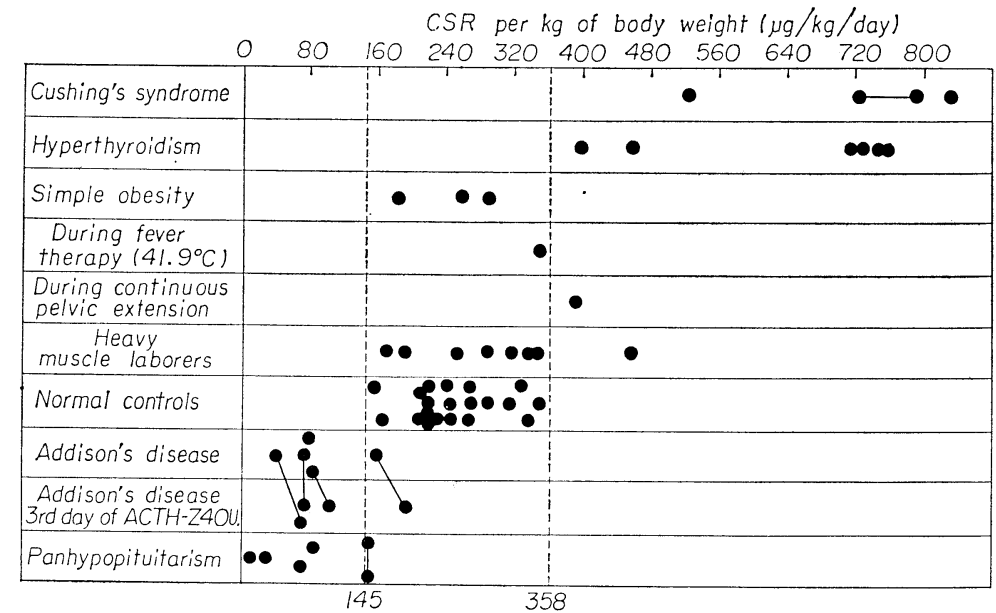

Dotted lines indicate the mean \pm 2 S.D. of CSR per $\mathrm{kg}$ of body weight in 20 normal controls, which may be justified as the normal range.

When viewed from the point of CSR per $\mathrm{kg}$ of body weight, cortisol hypersecretion in hyperthyroidism was most evident.

Further, simple obesity had CSR falling entirely within the normal range while Cushing's syndrome invariably showed elevated value, suggesting this criterion may have greater diagnostical value in differenciating these two clinical entities. 
Fig. 9. CSR of normal subjects, of those under stress and of patients with primary or secondary adrenocortical hyper- and hypotunction

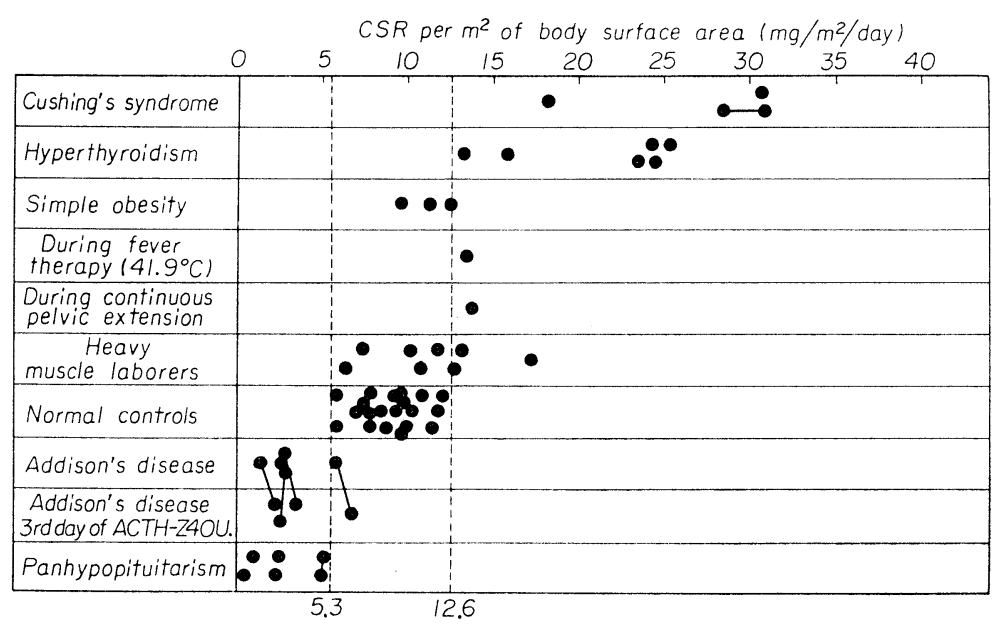

Dotted lines !ndicate the mean \pm 2 S.D. of CSR per $\mathrm{m}^{2}$ of body surface area in 20 normal controls, which may be justified as the normal range.

When viewed from the point of CSR per $\mathrm{m}^{2}$ of body surface area, simple obesity assumed rather high normal values.

た症状のない partial Addison’s disease の1 例(症例43)では, $7.9 \mathrm{mg} / \mathrm{day}$ と正常下界值を示した. Sheehan 症候群 2 例，並びに異所性 pinealoma 及び craniopharyngioma による汎下垂体機能低下症各 1 例では明 らかな低值を示した。しかし尿崩症，無月経及び粘膜水腫を伴い，SU 4885 亿対する反応は低下していたが glucocorticoid の置換療法は必要でなかつた Simmonds 症の1例（症例48）は，7.3及び $7.4 \mathrm{mg} / \mathrm{day}$ と正 常下界より僅かに低い值を示した。 この症例及び前述の partial Addison's disease の症例は, cortisol分泌 量の正常下界をての辺に設定するのが妥当であるてとを示唆しているように思われる.

以上の検討からは, 実際上 $8 \mathrm{mg} /$ day をもつて正常下界とするととに矛盾はないと思われた。 又, Cushing 症候群がいずれも明らかな高值を示したのにひきかえ, Addison 症や Simmonds 病が正常下界值をとりう るととは，臨床診断上留意すべきととと思われた。

単位体重あたり及び単位体表面積あたりの分泌量についても, 絶対値の場合と同様に検討した結果 (Fig. 8 及び 9), 甲状腺機能九進症における cortisol 過剩分泌は, 単位体重あたりの分泌量による場合に, 最も 判然と正常範囲から区別されることが明らかとなつた (Fig. 8).

又同じく単位体重あたりの分泌量による場合，単純性肥満症は全く正常範囲内に入り，Gushing 症候群は 依然として高值を示すととから，乙れによる比較検討が両者の鑑別に有用と考えられた(Fig. 8). 単位体表 面積あたりの分泌量による場合には, 単純性肥満症はどちらかといえば正常範囲内の高值を示した (Fig. 9). その他の面に関しては, 単位体重あたりの值でも, 単位体表面積あたりの值でも, cortisol 分泌量の絶対値 の場合とほぼ同程度の䛦断学的価值を有するものと認められる，従つて以上三者いずれの場合にも，平均值 \pm 2 S.D. の範囲を正常範囲として採用することが罗当と考えられる.

\section{第 5 章 結語}

Isotope dilution method による cortisol 分泌量測定の 1 方法を提示し, その信頼性について検討した. 又との方法を用いて正常対照例，重労働などのストレス下の被験例，並びに副腎皮質機能異常を有する諸疾 患例につき分泌量を測定し，それらの成績を対比して正常範囲を設定した。 
1) cortisol-1，2- ${ }^{3} \mathrm{H}$ を静注し，24時間家の一部を $\beta$-glucuronidase で水解し， ethyl acetate 抽出及び silica gel column そより得た crude extract から, ethylene dichloride-formamide system そより THF そ THE を分離し, 更に THF は Bush $\mathrm{B}_{5}$ system で, 又 THE は E2B system 或は Bush $\mathrm{B}_{5}$ system で精製し, liquid scintillation counting と Porter-Silber 反応により各々の比放射能を求め, cortisol 分 泌量を算出した。

2) THE の精製に E2B system を用いた場合, THE から算出した分泌量は THF から算出した分泌量

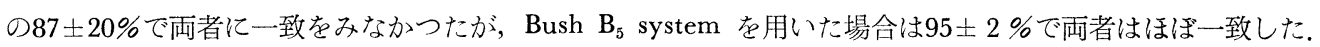

3）一定量 cortisol 内服中の hypoadrenocorticism 例につき見かけの分泌量を測定した結果，THF から 算出した分泌量は投与 cortisol 量の $99 \pm 26 \%$ ，平均としては投与量に一致したが，統計的誤差が大きいた め, 測定法全体としての系統的誤差を算出することは出来なかつた. この原因は断続的な cortisol 投与によ り, cortisol 代謝面での定常状態が破壊されたためと考えられた。 このように大きい統計的請差は, ほぼ定 常状態下に行なわれる一般の分泌量測定に際しては起り得ないと判断された。

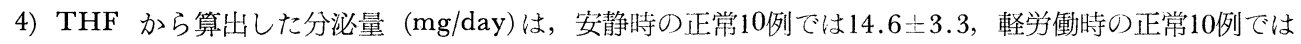
$13.7 \pm 3.2 て ゙ ，$ 両者間に有意差がなかつた。某炭鉱坑内の高温高湿環境下で採炭に従事する重労働者 8 例で は17.土5.0で, 平均值としては軽労働時のそれに比しやや高い值を示したが各測定值の大半は軽労働時のそ れの分布範囲内にあつた．以上の成績から安静時及び軽労働時各10例を併せた計20例をもつて正常対照とす るとととした. てれら正常対照20例における cortisol 分泌量の值は $14.1 \pm 3.2 \mathrm{mg} / \mathrm{day}$, 単位体重あたりで は $251 \pm 53 \mu \mathrm{g} / \mathrm{kg} / \mathrm{day}$, 単位体表面積あたりでは $8.9 \pm 1.8 \mathrm{mg} / \mathrm{m}^{2} / \mathrm{day}$ であつた. 上記分泌量は本邦でてれ までに報告された值の大部分と一致し, 又単位体重及び単位体表面積あたりの值は欧米諸国で報告された值 と一致した.

5）上記の各々の值について平均值 \pm 2 S.D. を正常範囲とした場合，正常対照20例はいずれの場合にも 全例ての範囲内に含まれた. cortisol 分泌量では Cushing 症候群全 3 例は明らかな高值を, 甲状腺機充能 進症全 6 例は正常上界より Cushing 症候群に匹敵する值を, 又単純性肥満症全 3 例はいずれも正常上界付 近の值を示した，重労㗢時の被験例の大半は正常範囲内に含まれた。（即ち職業として継続可能な程度の労 働によるストレスの大半は，cortisol 分泌量測定によつては識別しえないものと解される。)

一方 Addison 病 5 例中 4 例は明らかな低值を示したが, partial Addison’s disease の1例は正常下界值 を示した，又諸種の原因による汎下垂体機能低下症 5 例中 4 例は明らかな低值を示したが, 'glucococorticoid 置換療法を必要としなかつた Simmonds 病 1 例は正常下界値を示した.

6）単位体重あたり及び単位体表面積あたりの值についても同様に検討した結果，単位体重あたりの值の 場合, 単純性肥満症は全く正常範囲に含まれ, Cushing 症候群が依然として高值を示したととは, この 值による比較が両者の鑑別に有用なことを意味するものと思われた，その他の面て関してはてれらの值はい ずれも分泌量の絶対值とほぼ同程度の診断的価值を有するものと認められ，結局いずれの場合にも平均值 \pm 2 S.D. の範用死正常範囲とするととが罗当と考えられた。

尚, 本論文の要旨は第13回日本内分泌学会東部部会総会において発表した.

終りにのぞみ, 御指導を賜わつた三浦清博士, 福地総逸博士, 並びに御校閲を賜わつた鳥飼龍生教授に深 謝致します。

\section{文献}

1) EBERLEIN, W.R. and BONGIOVANNI, A.M. : Arch. Biochem. Biophys., $50: 90$, (1955). 2) BUSH, I.E. : Biochem. J., $50: 370$, (1952). $\quad$ 3) BURTON, R.B. et al : J. Biol. Chem., $188: 763$, (1951).

4) ULIGK, S. et al : Transact. Ass. Amer. Physicians, $71: 225$, (1958).

5) 堀内 淑彦他：ホルモンと臨林，12:507，（1964）。

6) BUSH, I.E. and WILLOUGHTY, M. : Biochem. J., $67: 689$, (1957).

7) OKАMOTO, M. : Endocrinol. Japon., 10 : 159, (1963).

8) BRAY, 
G.A. : Anal. Biochem., 1 : 279, (1960).

9) MEZEY, K.C. : Sugahara, I. (日本メルク万有K.K. 学術部) への Memo, (1962).

10）岡本正敏 : 著者への私信，(1963).

11) ROMANOFF, L.P. et al : J. Glin. Endocr., $21: 1413$, (1961). $\quad$ 12) MIGEON, G.J. et al : Metabolism, 12: 718, (1963). 13) BIGLIERI, E.J. et al : J. Clin. Invest., $42: 516$, (1963).

14) NEY, R.L. et al : J. Clin. Endocr., 22 : 1057, (1962). 15) FLOOD, C. et al : Acta Endocrinol., $36: 237$, (1961). 16) LAYNE, D.S. et al : J. Clin. Endocr., $22: 107$, (1962). 17 STEINGART, D.E. et al : Metabolism, $12:$ 484, (1963). 18) PETERSON, R.E. : J. Clin. Invest., $39: 320$ (1960). 19) VERMEULEN, A. and VAN DER STRAETEN, M. : J. Glin. Endocr., 23 : 574, (1963). 20) MONGLOA, F. and PRETELL, E. : J Clin. Endocr., $24: 915$; (1964). $\quad$ 21) MLYNARYK, P. et al : J. Glin. Endocr., $22: 587$, (1962). 22) KARL, H. J. and RAITH, L. : Klin. Wochenschrift, $43: 863$, (1965). 23) COPE, C.L. and BLACK, E. : Brit. Med. J., 1(No. 5078) : 1020, (1958). 24）井林博：代謝， 1：259，（1964）。 25）吉見輝也：日内分泌誌，41：51，（1965). 26）三方一沢他：日内分泌誌，41：285，（1965). 17) PETERSON, R.E. : J. Glin. Invest., 37 : 736, (1958). 28) HELLMAN, L. et al : J. Glin. Endocr., 21 : 1231, (1961). 29) BUSH, I.E. : The Chromatography of Steroids, (1961), 175, Pergamon Press, Oxford. 